\title{
THE EFFECT OF ESTROGEN ON WATER AND ELECTROLYTE METABOLISM. II. HEPATIC DISEASE
}

\author{
By JOHN R. K. PREEDY AND ELSIE H. AITKEN \\ (From the Medical Unit, The London Hospital, London, E. 1, England)
}

(Submitted for publication August 29, 1955 ; accepted December 28, 1955)

In chronic hepatic disease, the accumulation of fluid as ascites or edema is commonly observed (1). A similar tendency can also be demonstrated in acute hepatic disease, often in the absence of clinically detectable ascites or edema (2-4), suggesting that a common fluid-retaining factor may operate in both chronic and acute diseases.

Although diminished plasma colloidal osmotic pressure, resulting from lowered plasma albumen levels, has been put forward by some observers as the chief fluid-retaining factor in chronic liver disease (5-7) others have failed to find a constant correlation between the appearance of ascites and edema on the one hand and plasma albumen levels on the other $(8,9)$. Furthermore, the fluid retention of acute hepatic disease is not usually associated with abnormally low plasma albumen concentrations (2).

In search for other fluid-retaining factors, the possibility was suggested that in liver disease the hepatic inactivation of fluid-retaining hormones might be impaired, and from this point of view Ralli, Robson, Clarke, and Hoagland (10), investigated the role of the pituitary anti-diuretic hormone.

However, it seemed more probable that a primarily sodium-retaining hormone might be involved. Estrogens have been shown to have a salt-retaining action in animals (11), and there is much evidence to show that in animals these hormones are normally inactivated by the liver (12). Moreover, in human liver disease there are certain clinical features which are best explained on the basis of increased estrogen activity (13-15). These observations suggest that decreased inactivation of endogenous estrogen may occur in human liver disease, which may lead in turn to sodium-retention. Under these circumstances the administration of exogenous estrogen to cases of liver disease would be expected to result in far greater retention of sodium than in normal subjects (16).
The effect of the daily administration of estrogen on water and electrolyte metabolism has been studied in cases of human hepatic disease. To elucidate further the mechanism of the changes observed, the study was extended to include cases of obstructive jaundice, ascites without hepatic disease, and portal hypertension without hepatic disease.

\section{CLINICAL DATA}

Male and female cases were selected from the wards of The London Hospital. In no case was there evidence of cardiac or renal disease. In most cases, diagnosis was established by hepatic biopsy, at laparotomy or at subsequent post-mortem examination. Of the remainder only cases presenting typical clinical features were accepted.

Group 1-Hepatic cirrhosis with ascites ( 9 cases). The following categories were rejected: (a) Where accumulation of ascites was so rapid as to require paracentesis during the study. Only cases where ascites was accumulating or decreasing slowly were studied. (b) Where ascites could only be controlled by a low-Na diet. Control urinary $\mathrm{Cl}$ and $\mathrm{Na}$ levels under these circumstances were too low to enable the effect of estrogen to be adequately observed. (c) Where ascites had occurred only as a temporary episode complicating hematemesis. Two cases (Nos. 33 and 62) where ascites was about to develop were accepted, together with one (No. 56) where a chronic ascites had recently disappeared with treatment in hospital. One case (No. 62) was studied twice at different stages of the disease.

Group 2-Hepatic cirrhosis without ascites (12 cases). Cases in whom there was a past history of ascites only as a temporary episode complicating hematemesis were included. Two cases were studied twice at different stages of the disease (Nos. 16 and 22). Both early and advanced cases were included.

Group 3-Infective hepatitis (4 cases). All cases in this group (except No. 48) showed signs of recovery by the time estrogen was administered. Infective hepatitis occurred rarely during the period of these studies and only one case (No. 48) in the most severe category was available.

Group 4-Obstructive jaundice (5 cases). Only cases with chronic and apparently complete obstruction of the biliary passages were accepted. Cases of gall stones were excluded. 


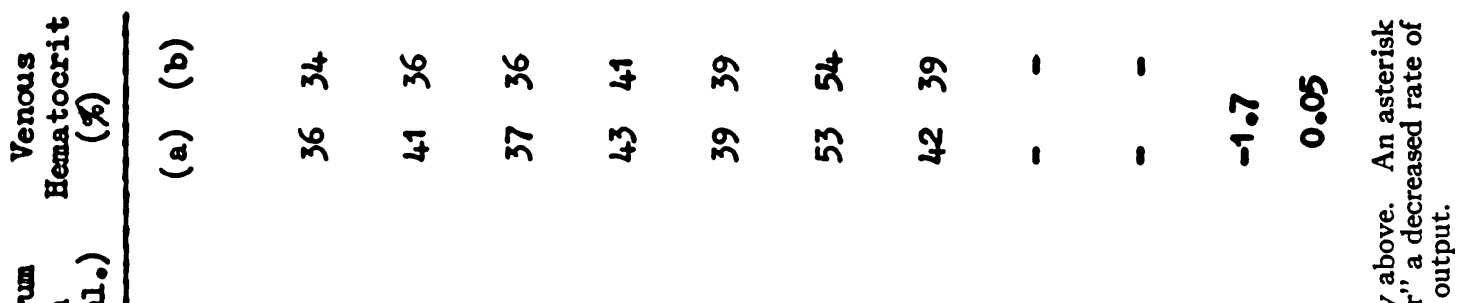
\&

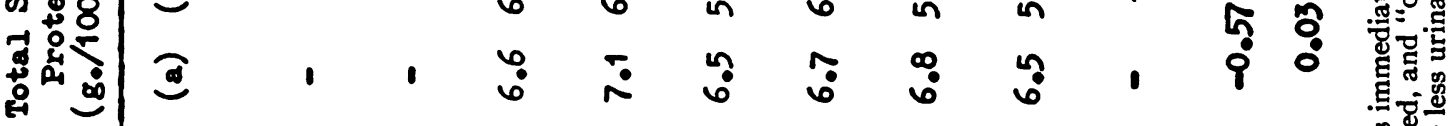

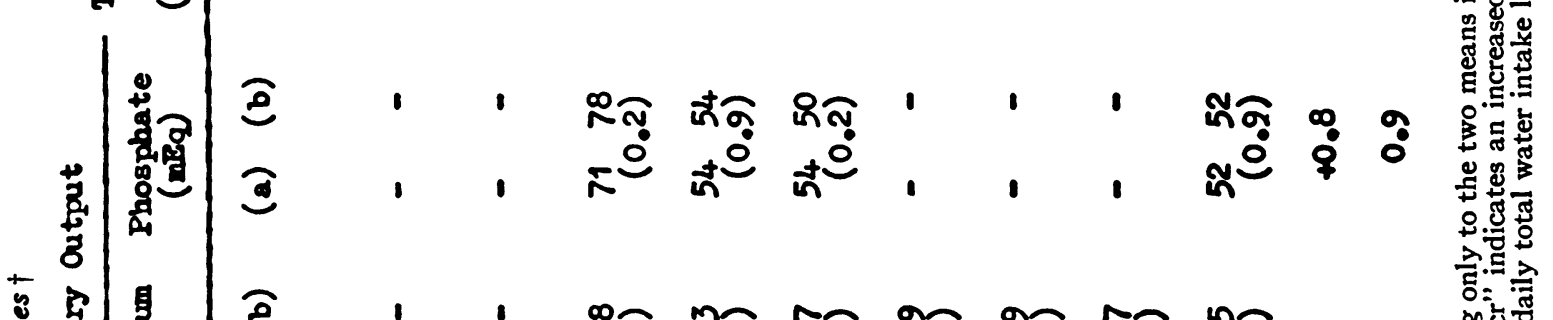

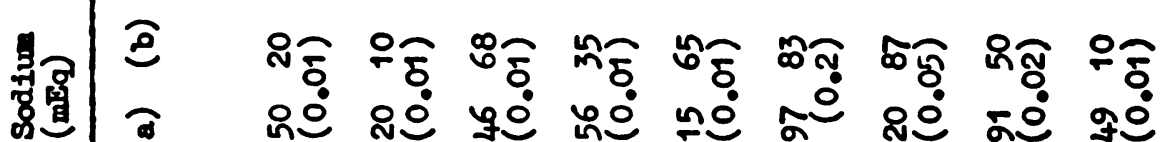

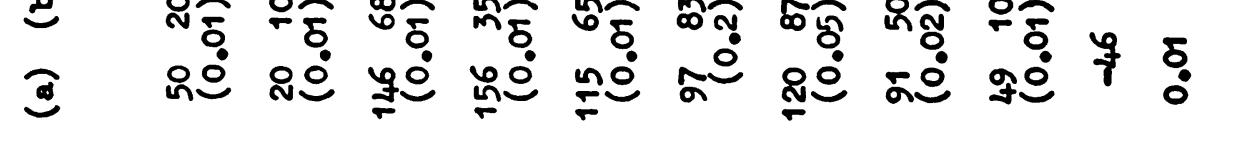

.E II

( 120

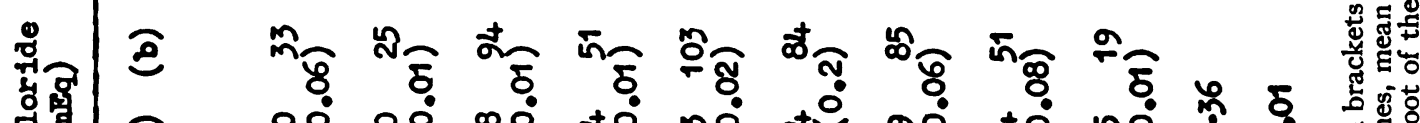

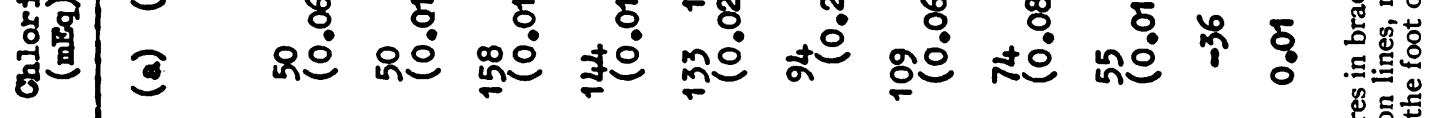

(2)

ชุำ

อ

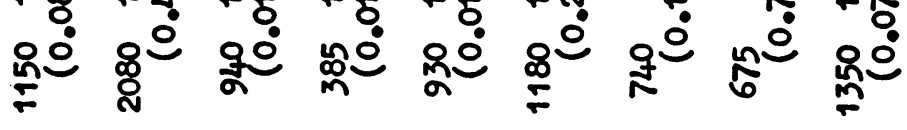

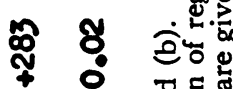

远政

要曷

(3) 윻

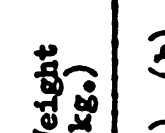

อ

อ

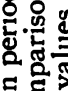

路口

है.

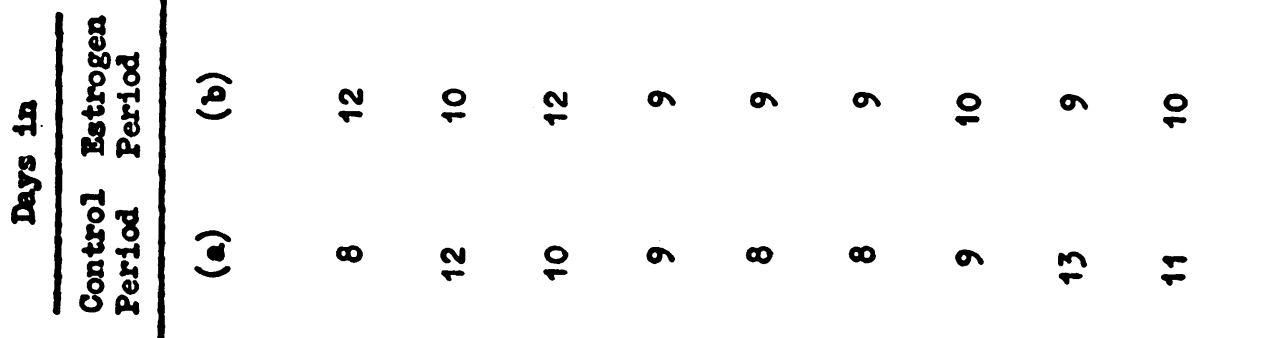

:

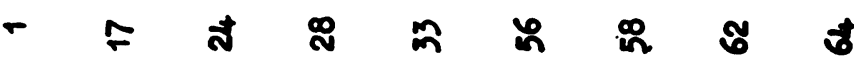

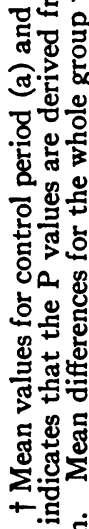




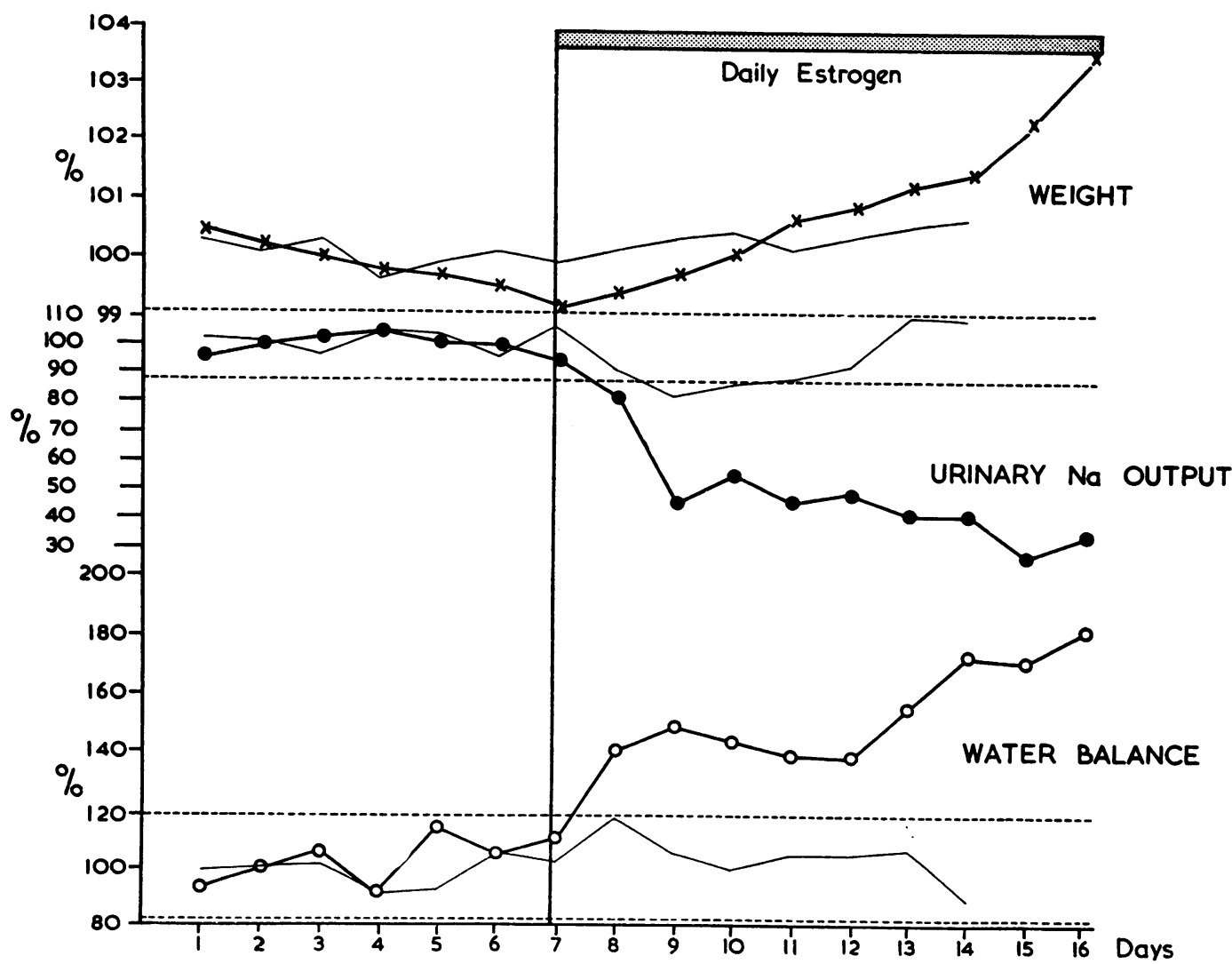

Fig. 1. The Effect of Estrogen Administration on Daily Weight, Urinary Sodium Output and Water Balance in Cirrhosis With Ascites

Control period, days 1 to 6; estrogen period, days 7 onwards. Each point represents the daily average for the group expressed as a percentage of the control period mean. Water balance $=$ daily total water intake less urinary output. Horizontal interrupted lines denote the 95 per cent confidence limits for the control period for each class of observation. Results in the normal group are inserted for comparison (continuous line).

Group 5-Ascites without hepatic disease (3 cases). Cases were chosen where hepatic, cardiac or renal disease could be excluded. Cases were not accepted in which ascites was accumulating so rapidly that paracentesis might become necessary during the study, or in which ascites could only be controlled by a low $\mathrm{Na}$ diet. Two cases had carcinomatosis peritonei and one had tuberculous peritonitis.

Group 6-Portal hypertension without hepatic disease ( 2 cases). In the two cases in this group portal hypertension was due to splenic vein thrombosis. Liver function tests were normal, hepatic biopsy showed normal histology, and the liver appeared normal at laparotomy. There was no ascites.

The balance study, estradiol dosage, estimations, methods and presentation of results are as described in the previous paper (16) with the following exceptions. The "thiocyanate space" was not determined in cases with ascites, due to difficulty in obtaining an equilibrium CNS concentration between plasma and ascitic fluid. In statistical analysis an extended use was made of regres- sion line comparisons, particularly in the analysis of weight trends. Values for $P$ (derived from the $t$ test) of between 0.03 and 0.05 were regarded as of "borderline significance." In calculating group mean differences for weight, cases where there was an obvious trend during the control period (marked by an asterisk in Tables I to IV) were omitted.

\section{RESULTS}

\section{Cirrhosis with ascites (Table I)}

Weight. The group mean difference between control and estrogen periods was calculated only from the four cases (Nos. 33, 56, 58, and 62) in which there was no obvious trend during the control period. In the remaining cases, regression lines were calculated for both periods. In all these subjects (except No. 17) a highly significant difference between control and estrogen regres- 
sion lines was observed, the difference indicating an increased rate of weight gain during the estrogen period in case 1 , and a slightly decreased rate of gain in case 64 . In cases 24 , and 28 there was a complete reversal of a downward trend following estrogen administration. In cases $33,56,58$, and 62 , the significance of differences between means could be tested. There was a significant increase of weight in cases 33,56 , and 58.

Water balance. There was a group mean difference between periods of $+283 \mathrm{ml}$. which was significant. In individual cases an increased mean figure was observed in all cases, except in No. 17, but the difference was of a magnitude to attain significance only in cases 24,28 , and 33 .

Daily urinary outputs. $\mathrm{Cl}$ and $\mathrm{Na}$. There was a group mean difference between periods of -36 $\mathrm{mEq}$. $\mathrm{Cl}$ and $-46 \mathrm{mEq}$. $\mathrm{Na}$, each difference being highly significant. A significantly decreased mean output of $\mathrm{Cl}$ and $\mathrm{Na}$ during the estrogen period was observed in each subject, except in Nos. 56, 58, and 62. In No. 58 the decrease in both $\mathrm{Cl}$ and $\mathrm{Na}$ was of borderline significance, and in case 62 the decrease in $\mathrm{Na}$ was significant, but that in $\mathrm{Cl}$ was not. In case 56 no significant variation in either $\mathrm{Cl}$ or $\mathrm{Na}$ occurred during the estrogen period.

$K$. This estimation was performed in seven cases. There was no significant difference between periods as a group. In case 56 , there was a small but significant increase in average output of $\mathrm{K}$, and in case 64 a small but significant decrease.

PO4. Phosphate output was studied in four cases. The group mean difference was not significant and there was no significant difference between period means in any individual case.

Total serum protein. There was a mean decrease of $0.57 \mathrm{~g}$. per $100 \mathrm{ml}$., which was of borderline significance. This represents a mean decrease of 8 per cent of control values.

$V$ enous hematocrit. A mean decrease of 1.7 per cent was observed in the seven cases in which this observation was made. The significance was borderline. This represents a mean decrease of 4 per cent of control values.

Plasma $\mathrm{Cl}$ and $\mathrm{Na}$. No significant variation in concentration was observed following the administration of estrogen ( $\overline{\mathrm{d}}=-0.3 \mathrm{mEq}$. per $\mathrm{L}$. $[P=0.8]$ and $+0.7 \mathrm{mEq}$. per L. $[P=0.8]$, respectively).

Water tolerance test. Mean results for the five cases studied are given in Table IV. The hourly differences were either non-significant or of borderline significance, but the mean difference for all hours and all cases $(-67 \mathrm{ml}$.) was highly significant $(P=0.01)$.

In contrast to the normal findings there was a marked and sustained fall in daily average urinary $\mathrm{Na}$ output (Figure 1), accompanied by an

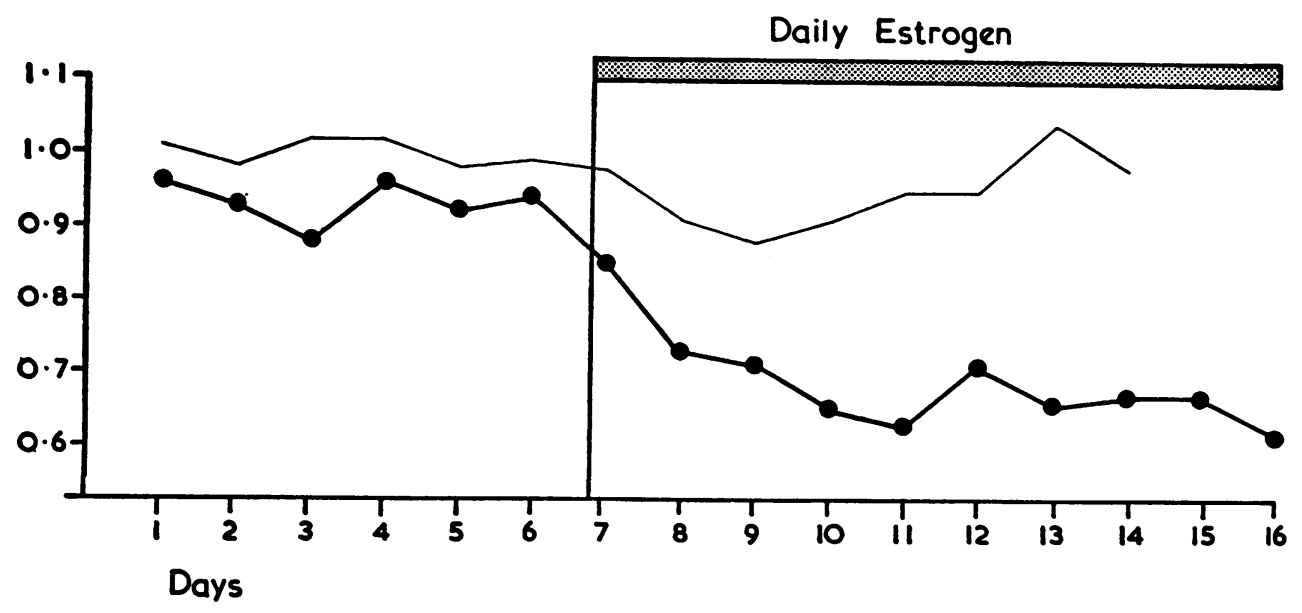

Fig. 2. The Effect. of Estrogen Administration on the Daily Urinary Na/Cl Ratio in Cirrhosis with Ascites

Control period, days 1 to 6; estrogen period, days 7 onwards. Each point represents the daily average for the group. Results in the normal group are inserted for comparison (continuous line). 


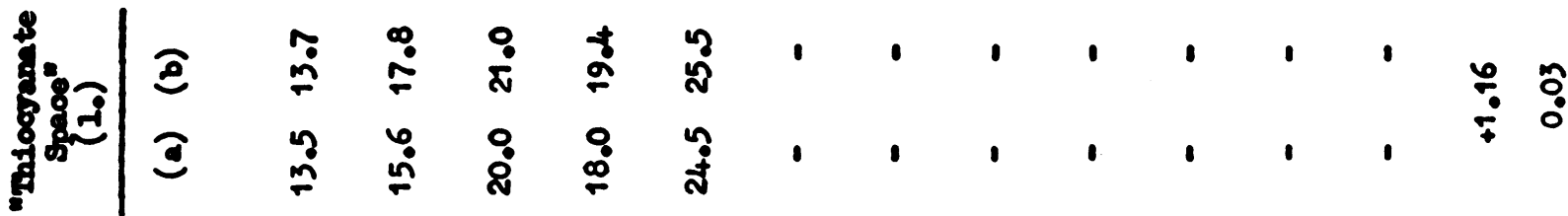
8. รุํำ อ

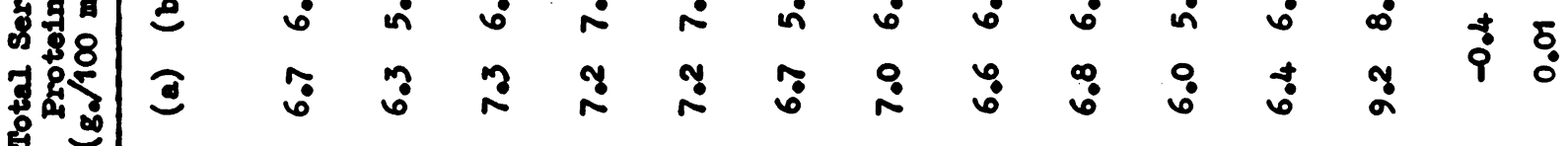

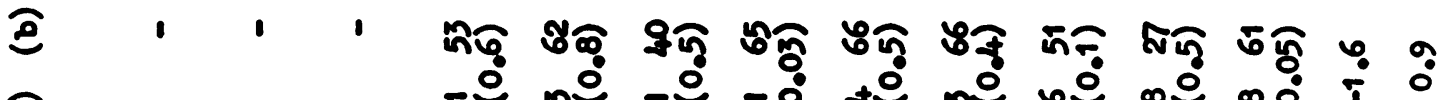
(2) . ,

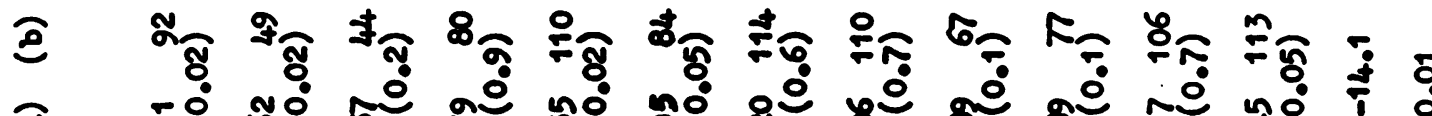
(2) ₹0

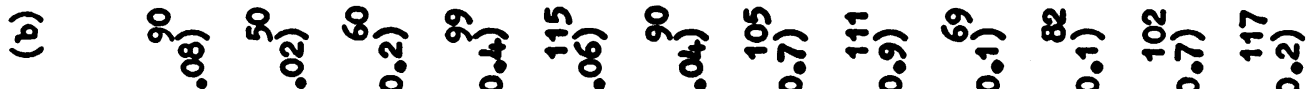

- 잉

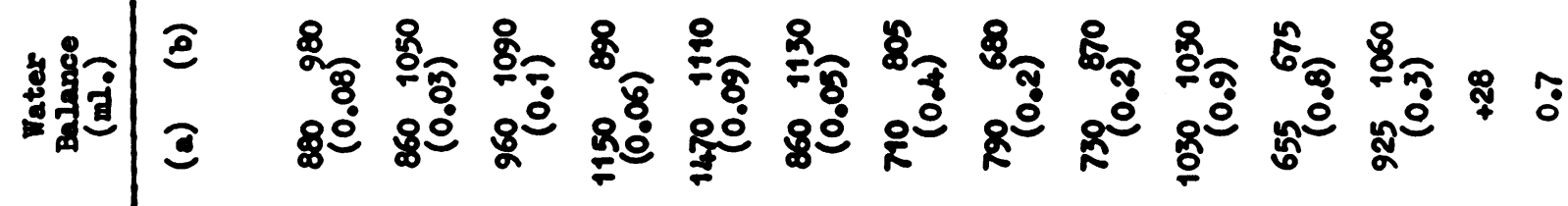

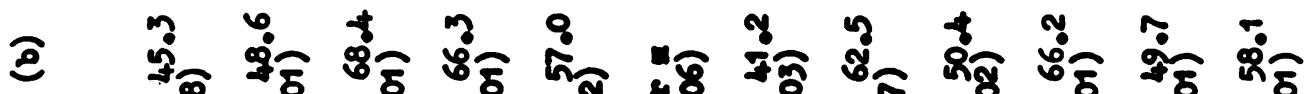

(2)

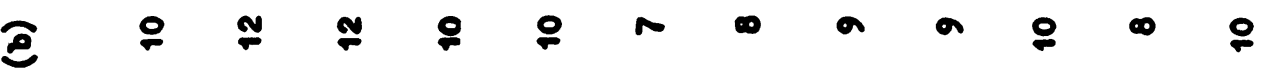


equally sustained rise in water balance and in weight during the estrogen period. The extent of the 95 per cent confidence limits for the cirrhotic group indicates the high degree of significance of these findings. The figures for weight are necessarily cumulative, and, since there was a steady fall during the control period, the increase following estrogen administration should be measured from the last day of the control period and not from the control mean. The extent of weight gain is then seen to be far greater than in the normal.

Daily average urinary $\mathrm{Na} / \mathrm{Cl}$ output ratios (Figure 2) decreased from a control mean of 0.94 to a sustained level of approximately 0.67 during estrogen administration, in contrast to normal values.

There was an average apparent retention during the estrogen period of $325 \mathrm{mEq}$. $\mathrm{Na}, 218 \mathrm{mEq}$. $\mathrm{Cl}$,

TABLE II

The effect of estrogen administration in obstructive jaundice, infective hepatitis, ascites without hepatic disease and portal hypertension without hepatic disease $\dagger$
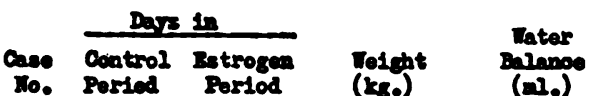

Dats oring outpht

10. Perted Pertod

(kes)

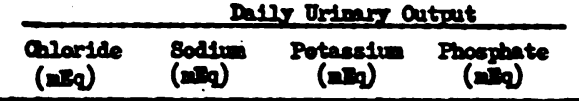

Dtal serw.

Proteln

(a) (b)

(a) (b)

(a) (b)

(a) (b)

(a) (b)

(a) (b)

(a) (b)

(a) (b)

Tenatoort

QBSTROCLIVS JAWIDIC.

$\begin{array}{ccc}3 & 7 & 7 \\ 23 & 5 & 8 \\ 40 & 6 & 10 \\ 42 & 6 & 10\end{array}$

$$
\begin{gathered}
51.2494+650 \text { (0.4) } \\
(0.01)^{820}
\end{gathered}
$$

$\begin{array}{cc}155 & 114 \\ (0.01)^{165} & (0.1)^{147}\end{array}$

$45.6 \quad 45.2$

$(0.7)$

840.880

$75{ }^{61} \quad{ }^{69} \quad(0.1)^{43}$

6055

$-$

$-$

${ }_{(0.01)}^{43.42 .6} \quad{ }_{(0.1)^{715}}^{600}$

$70.2)^{70} \quad{ }_{(0.4)^{62}}$

51.46
$(0.04)$

${ }^{50}(0.7)$

$6.6 \quad 5.2$

4439

$$
57.2(0.6)^{-1}{ }^{1450}(0.5)^{1570}
$$

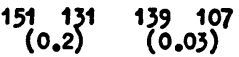

85.74
$(0.05)$

61
$(0.9)$

7.26 .5

4239

42

$$
57.9 \quad 57.411651460
$$

$10280 \quad 5141$

3933
$(0.06)$

6051
$(0.7)$

$5.5 \quad 5.3$

3836

Yoan difference

$\begin{array}{cc}-0.7 & +148 \\ 0.08 & 0.08\end{array}$

-18.8
0.08

$-20.8$

$-9.2$

73,65

$\begin{array}{llll}5.9 & 5.8 & 32 & 30\end{array}$

DVECTIVE HEPATITTS

$\begin{array}{ccc}2 & 6 & 13 \\ 10 & 10 & 11 \\ 48 & 6 & 9 \\ 75 & 7 & 9\end{array}$

Yoan differenoo

$\mathbf{P}$

$$
\begin{aligned}
& \begin{array}{cc}
54.7 & 57.7 \\
(0.01)^{1085} & (0.2)
\end{array} \\
& \begin{array}{cc}
42.8 & 43.44 \\
(0.01)^{1230} & (0.01)^{1380}
\end{array}
\end{aligned}
$$$$
\text { incr } \quad 215.0995
$$$$
\begin{gathered}
61.6 .61 .8 \\
(0.1) \\
(0.05)^{1210}
\end{gathered}
$$

$$
+418
$$$$
0.04
$$$$
217206
$$

$\begin{array}{llll}96 & 110 & 108 & 108\end{array}$

(0.3)

(0.7)

$249167 \quad 260 \quad 168$

\begin{tabular}{|c|c|c|c|c|c|c|c|c|c|c|c|}
\hline 25 & 10 & 10 & $\frac{\operatorname{lnor}}{(0.01)^{2}}$ & $\begin{array}{c}12001270 \\
(0.5)\end{array}$ & $\frac{1 \operatorname{lnax}=}{(0,01)^{2}}$ & $\begin{array}{l}\text { inar } \\
(0.01)\end{array}$ & $\begin{array}{c}62 \quad 62 \\
(0.9)\end{array}$ & $\begin{array}{l}50 \\
(0.017)\end{array}$ & 6.5 & 6.5 & 47 \\
\hline 35 & 14 & 10 & $\operatorname{lnor}_{(0,01)}$ & ${ }^{1040}(0,4)^{970}$ & $\begin{array}{c}128107 \\
(0.09)\end{array}$ & ${ }^{127}\left(\begin{array}{r}105 \\
0.06)\end{array}\right.$ & $\begin{array}{l}5048 \\
(0.6)\end{array}$ & $(0.7)$ & 7.2 & 6.3 & 38 \\
\hline 66 & 8 & 9 & $\begin{array}{c}60.5 \\
(0.07)^{57.6}\end{array}$ & ${ }^{171}(0.01)^{504}$ & $\begin{array}{l}170115 \\
(0.01)^{115}\end{array}$ & $\begin{array}{rr}188 & 123 \\
(0.01)\end{array}$ & $\begin{array}{l}64 \\
(0.03)\end{array}$ & $-\quad-$ & - & - & - \\
\hline
\end{tabular}

92.91

96.87

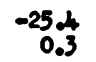

$-20$

ASCTIESS WITHOOT BISPATIC DISEAST

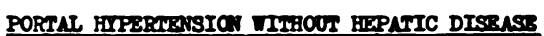

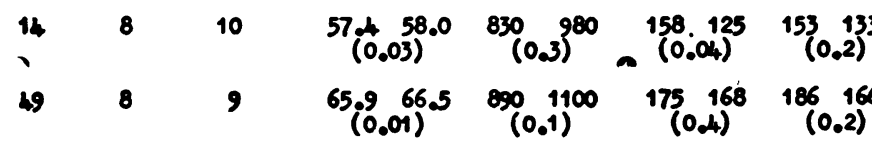

† See footnote, Table I.

$\begin{array}{ccc}-3.8 & -0.48 & -3 \\ 0.3 & 0.2 & 0.01\end{array}$


and $1950 \mathrm{ml}$. water. There was an average gain of weight of $2.06 \mathrm{~kg}$. These values are in approximately the expected proportion, if the changes observed were due to an increase in the volume of extracellular fluid (ECF). Since intake remained constant and there were no abnormal losses, these findings taken together indicate that the retention of $\mathrm{Cl}, \mathrm{Na}$, and water was in fact due to an increase in ECF volume.

\section{Cirrhosis without ascites (Table II)}

Weight. There was no significant difference between periods in the group as a whole. There was, however, a significant increase in weight in five individual cases (Nos. 18, 19, 22, 70, and 71), and a significant decrease in two (Nos. 72 and 73).

Water balance. The group mean difference of $+28 \mathrm{ml}$. was not significant. There was no significant difference between period means in any case, but in No. 18 a difference of $+190 \mathrm{ml}$. was of borderline significance.

Daily urinary outputs. $\mathrm{Cl}$ and $\mathrm{Na}$. There was a small but significant difference between control and estrogen periods in both $\mathrm{Cl}$ and $\mathrm{Na}$ outputs, group mean differences being $-10.0 \mathrm{mEq} . \mathrm{Cl}$ and $-14.1 \mathrm{mEq}$. Na.

No significant difference was observed in in-
TABLE IV

Water tolerance tests *

\begin{tabular}{|c|c|c|c|c|c|}
\hline \multirow[b]{2}{*}{$\begin{array}{l}\text { No. of } \\
\text { subjects }\end{array}$} & \multicolumn{5}{|c|}{ Urinary volume (ml:) } \\
\hline & $\begin{array}{c}\text { 1st } \\
\text { hour }\end{array}$ & $\begin{array}{l}\text { 2nd } \\
\text { hour }\end{array}$ & $\begin{array}{c}\text { 3rd } \\
\text { hour }\end{array}$ & $\begin{array}{l}\text { 4th } \\
\text { hour }\end{array}$ & $\begin{array}{c}\text { All four } \\
\text { hours }\end{array}$ \\
\hline \multicolumn{6}{|c|}{ Cirrhosis with ascites } \\
\hline 5 & $\begin{array}{r}-80 \\
(0.2)\end{array}$ & $\begin{array}{r}-113 \\
(0.04)\end{array}$ & $\begin{array}{c}-51 \\
(0.03)\end{array}$ & $\begin{array}{c}-25 \\
(0.06)\end{array}$ & $\begin{array}{c}-67 \\
(0.01)\end{array}$ \\
\hline \multicolumn{6}{|c|}{ Cirrhosis without ascites } \\
\hline 5 & $\begin{array}{l}-25 \\
(0.7)\end{array}$ & $\begin{array}{l}-100 \\
(0.01)\end{array}$ & $\begin{array}{c}-22 \\
(0.6)\end{array}$ & $(0.8)^{9}$ & $\begin{array}{c}-39 \\
(0.06)\end{array}$ \\
\hline \multicolumn{6}{|c|}{ Obstructive jaundice } \\
\hline 5 & $\begin{array}{r}+3 \\
(0.3)\end{array}$ & $\begin{array}{c}+58 \\
(0.6)\end{array}$ & $\begin{array}{c}-20 \\
(0.7)\end{array}$ & $\frac{-58}{(0.1)}$ & $\frac{-16}{(0.6)}$ \\
\hline
\end{tabular}

* Figures represent the group mean differences between control period and estrogen period tests ( $P$ figures are in parentheses).

dividual cases, except in Nos. 16, 18, and 39. In cases 16 and 39 there was a small but significant decrease in $\mathrm{Na}$ output alone during the estrogen period; in No. 18 a significant decrease was observed in both $\mathrm{Cl}$ and $\mathrm{Na}$.

$K$. There was no significant difference between periods as a group nor in any of the nine cases in which the estimation was done.

Total serum protein. There was a significant decrease, mean difference being -0.4 g. per 100

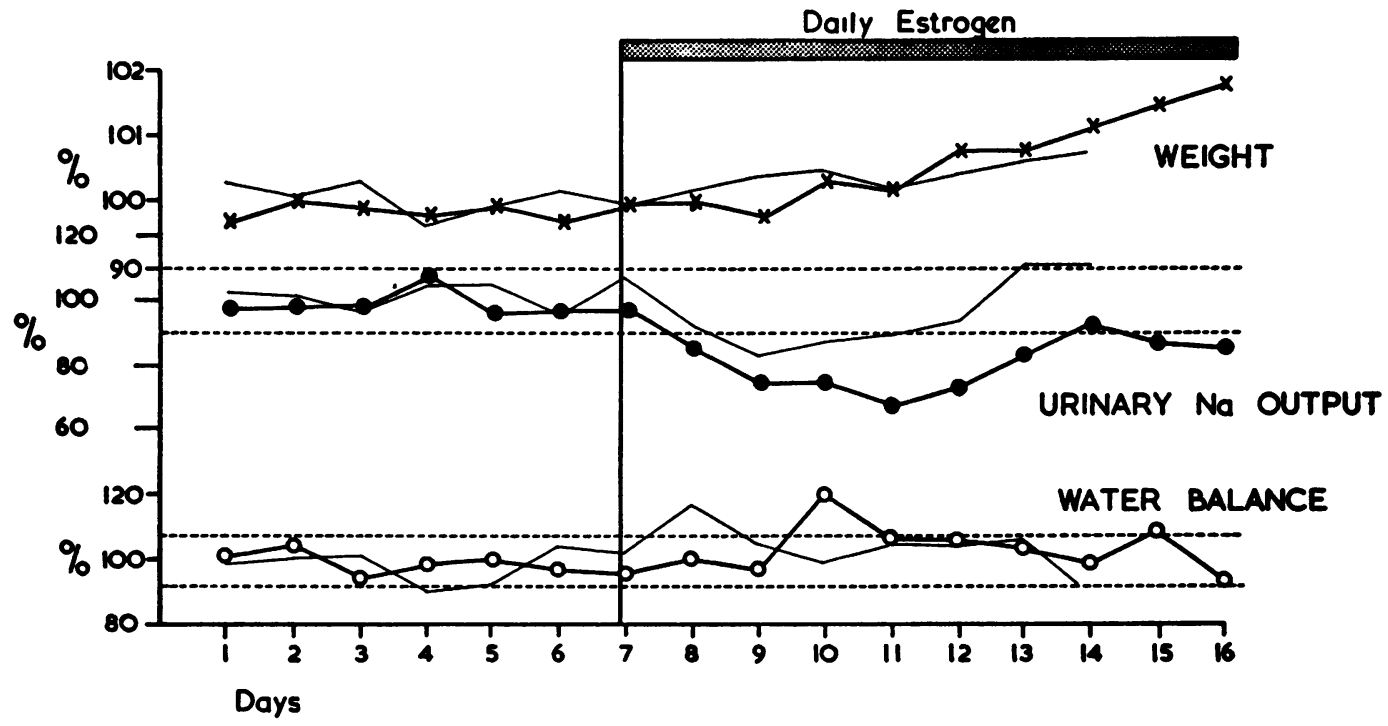

Fig. 3. The Effect of Estrogen Administration on Daily Weight, Urinary Sodium OUtPUt and Water Balance in Cirrhosis without Ascites

See footnote, Figure 1. 
$\mathrm{ml}$. This represents a decrease of 5.5 per cent of control values.

Venous hematocrit. A mean decrease of 1.2 per cent was not significant. This estimation was done on seven cases. It represents a decrease of 3.0 per cent of control values.

"Thiocyanate space." This observation was made in five cases only. There was a mean increase of $1.16 \mathrm{~L}$. which was of borderline significance.

Plasma $\mathrm{Cl}$ and $\mathrm{Na}$ levels. No significant change was observed in the level of either ion (group mean differences, $+0.2 \mathrm{mEq}$. per $\mathrm{L}$. $\mathrm{Cl}$ and +0.6 $\mathrm{mEq}$. per L. $\mathrm{Na}, \mathrm{P}=0.8$ in each case).

Water tolerance test (Table IV). This test was performed in five cases. The group mean difference between periods for all hours and all cases of $-39 \mathrm{ml}$. was not significant. Analysis of results by hours shows that there was a significant difference following estrogen administration only in the second hour $(\overline{\mathrm{d}}=-100 \mathrm{ml} ., \mathrm{P}=0.01)$.

Figure 3 indicates that there was no marked difference between the cirrhotic group and the normal in respect of average daily weight or water balance, but average daily $\mathrm{Na}$ outputs in the cirrhotic group were somewhat lower during the estrogen period. In addition, the $\mathrm{Na}$ output failed to return to the control mean in nine days, whereas in the normal group, values rose above the control mean in seven days. Daily average urinary $\mathrm{Na} / \mathrm{Cl}$ ratios did not differ significantly from the normal.

There was an average apparent retention of 126 mEq. $\mathrm{Na}, 99 \mathrm{mEq} . \mathrm{Cl}$, and $266 \mathrm{ml}$. water and an average weight gain of $0.74 \mathrm{~kg}$. during the estrogen period. $\mathrm{Na}$ and $\mathrm{Cl}$ were retained in approximately the proportion expected, if retention were solely due to increased extracellular fluid volume, but the apparent retention of water and the increase in weight were not in the expected proportions.

\section{Obstructive jaundice (Table III)}

Weight. There was, as a group, no significant change during the estrogen period. Individual records show either no significant change (Nos. $23,40,42$ ), or a small but significant decrease of weight during the estrogen period (Nos. 3 and 29). However, inspection of the individual records in these two cases indicated that a decreasing tendency was already evident during the last days of the control period, although there was no systematic tendency throughout the period as a whole.

Water balance. No significant variation occurred as a group during the estrogen period nor was there any significant variation in any individual case.

Daily urinary outputs. $\mathrm{Cl}$ and $\mathrm{Na}$. There was a significant decrease in $\mathrm{Cl}$ and $\mathrm{Na}$ (group mean differences, $-18.8 \mathrm{mEq}$. $\mathrm{Cl}$, and $-20.8 \mathrm{mEq}$. $\mathrm{Na}$, $\mathrm{P}=0.02$ in each case).

In individual cases, there was a significant decrease in $\mathrm{Cl}$ output alone in cases 3 and 42, and a decrease in $\mathrm{Na}$ output alone of borderline significance in cases 23 and $40(P=0.03)$.

$K$. This estimation was done in four cases. A group mean difference of $-9.2 \mathrm{mEq}$. was of borderline significance $(P=0.04)$. A decrease of borderline significance also occurred in two individual subjects (Nos. 29 and 40).

$P O_{4}$. There was no significant variation as a group nor was there any significant difference in any of the four individual cases.

Venous hematocrit. There was a highly significant mean decrease in packed cell volume of 3 per cent $(P=0.01)$. This represents a decrease compared with control values of 7.5 per cent.

There was no significant change in either total serum protein levels or in thiocyanate space (mean difference for thiocyanate space +1.9 L., $\mathrm{P}=$ $0.1)$.

Plasma $\mathrm{Cl}$ and $\mathrm{Na}$. There was no significant change following estrogen administration (group mean difference $+0.2 \mathrm{mEq}$. per $\mathrm{L}$. $\mathrm{Cl}$ and +0.4 mEq. per L. $\mathrm{Na}, \mathrm{P}=0.9$ in each case).

Water tolerance test (Table IV). The mean difference between control and estrogen periods for all cases and all hours was not significant. Analysis of hourly results indicated no significant difference between periods for any hour.

Figure 4 shows that $\mathrm{Na}$ output decreased well below the normal range, but rose above control levels by the end of the estrogen period. Water balance rose above the 95 per cent confidence limits, then returned to control values, the variation corresponding to that of $\mathrm{Na}$ output. Weight which had been falling steadily during the control period, rose during the estrogen period. Average daily urinary $\mathrm{Na} / \mathrm{Cl}$ ratios did not however vary significantly between periods. 


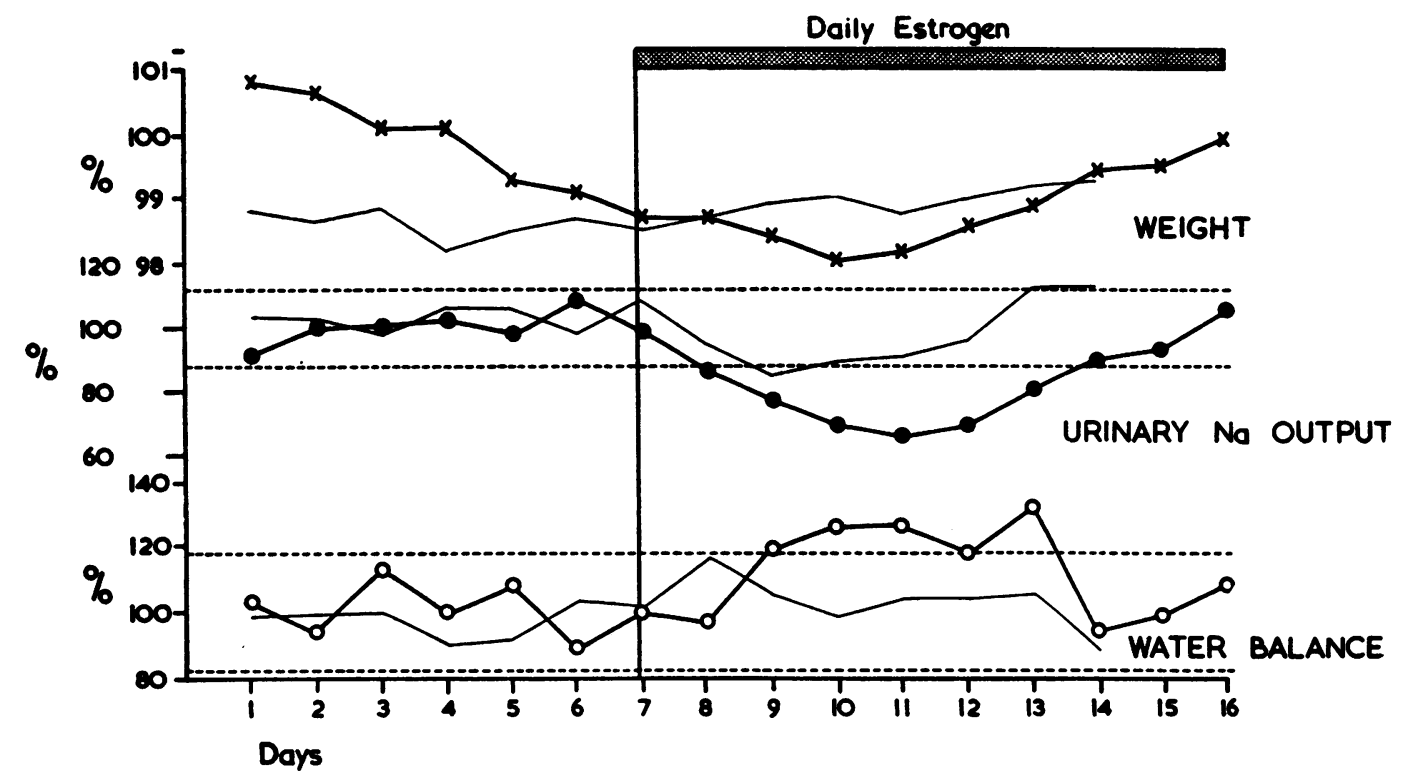

Fig. 4. The Effect of Estrogen Administration on Daily Weight, Urinary Sodium Output and Water Balance in Obstructive Jaundice

See footnote, Figure 1.

There was an average apparent retention of 178 mEq. $\mathrm{Cl}$ and $167 \mathrm{mEq}$. $\mathrm{Na}$, and $1360 \mathrm{ml} . \mathrm{H}_{2} \mathrm{O}$ during the estrogen period. There was an average increase in weight (estimated from the last day of the control period) of $0.25 \mathrm{~kg}$. These figures are not in the proportion expected if retention were due solely to an increase in ECF volume.

\section{Infective hepatitis (Table III).}

Weight. (Group analysis was not attempted.) There was a significant increase in weight during the estrogen period in cases 2,10 , and 48 , being particularly marked in No. 2. In No. 48 , the falling tendency during the control period was reversed following estrogen administration.

Water balance. There was a group mean difference of $+418 \mathrm{ml}$. between periods, which was of borderline significance $(P=0.04)$. In cases 10 and 48 , there was a significant increase in water balance during the estrogen period. In case 75 the increase was of borderline significance $(P=$ 0.05 ), and in case 2 non-significant.

Daily urinary outputs. $\mathrm{Cl}$ and $\mathrm{Na}$. There was no significant group mean variation between periods in the output of either ion. In case 48 , there was a significant fall in urinary $\mathrm{Cl}$ and $\mathrm{Na}$ output during the estrogen period. In the remaining cases there was no significant change.
No significant change was observed in urinary $\mathrm{K}$ output, nor in total serum protein, venous hematocrit and plasma $\mathrm{Cl}$ and $\mathrm{Na}$ levels. Water tolerance tests were carried out in three cases; there was no significant difference between periods.

In the four cases of infective hepatitis estrogen administration had no significant effect as a group on water balance or on urinary $\mathrm{Cl}$ and $\mathrm{Na}$ output. However, a significant decrease in urinary $\mathrm{Na}$ and $\mathrm{Cl}$ output, accompanied by a significant increase in weight and water balance, did occur in case 48 . Here an $\mathrm{NaCl}$ and water diuresis was temporarily reversed on estrogen administration. The individual record showed that a second diuresis occurred when estrogen was discontinued.

\section{Ascites without hepatic disease (Table III)}

Group analysis was not carried out in these three cases. In case 25 , there was a steady increase in weight during the control period due to the accumulation of ascites. Estrogen administration was accompanied by a slight but significant increase in the rate of weight gain. There was a progressive decrease in urinary $\mathrm{Na}$ and $\mathrm{Cl}$ output during the control period, comparison of regression lines indicating that the rate of decrease became significantly less during the estrogen period. A 
significant mean decrease in urinary $\mathrm{PO}_{4}$ output was observed during the estrogen period, and there was a reduction in venous hematocrit of 2 per cent.

In case 35 , there was a steady decrease in weight during the control period, which was significantly reversed during the estrogen period $(P=0.01)$. No significant change was observed in urinary output of $\mathrm{Cl}, \mathrm{Na}, \mathrm{K}$, or $\mathrm{PO}_{4}$, but total serum protein decreased by $0.9 \mathrm{~g}$. per $100 \mathrm{ml}$., and the venous hematocrit by 4 per cent. Case 66 was undergoing a slow spontaneous diuresis during the control period. The significant decrease in weight during the estrogen period was attributable to this factor, which also accounted for the significant diminution in water balance, and urinary $\mathrm{Na}$ and $\mathrm{Cl}$ output. A slight decrease in $\mathrm{K}$ output was of borderline significance.

Plasma $\mathrm{Cl}$ and $\mathrm{Na}$ levels were not significantly affected by estrogen administration in any of these cases. Water tolerance tests performed in cases 25 and 35 showed a mean difference between periods for both cases and all hours of $-131 \mathrm{ml}$., which was of borderline significance $(P=0.03)$.

There was no indication in any of the three cases that estrogen caused any significant alteration in $\mathrm{NaCl}$ and water metabolism.

\section{Portal hypertension without hepatic disease (Table III)}

Group analyses were not carried out. In both cases studied there was an increase of weight following estrogen administration, significant in case 49 and of borderline significance in case 14 . This was not reflected in any significant decrease in water balance or urinary output of $\mathrm{Cl}$ or $\mathrm{Na}$. A mean difference of $\mathrm{Cl}$ only $(-33 \mathrm{mEq}$.) in case 14 was of borderline significance. Urinary $\mathrm{K}$ and $\mathrm{PO}_{4}$ outputs in case 49 were not significantly affected. Plasma $\mathrm{Cl}$ and $\mathrm{Na}$ and total serum protein levels were not significantly changed. A decrease in hematocrit of -2 per cent in case 14 was observed. The water tolerance test showed no significant change between periods in either case.

There was no indication that estrogen caused any significant retention of water or $\mathrm{NaCl}$ in either case.

\section{DISCUSSION}

The considerable and sustained retention of $\mathrm{Cl}$, $\mathrm{Na}$, and water observed in the group of cirrhosis with ascites following the administration of estrogen is in marked contrast with the effect of the same dosage in the normal (16). The changes in the cirrhotic group were apparent not only in the group as a whole (Table I, Figure 1 and 2) but also in each individual case, save one (No. 56) in which ascites had already disappeared following six weeks' hospital treatment.

In the group of cirrhosis without ascites, on the other hand, the effect of estrogen on $\mathrm{NaCl}$ and water metabolism did not differ markedly from the normal. However, although no significant change occurred in any individual case, save one (No. 18), a small but significant retention of $\mathrm{Cl}$ and $\mathrm{Na}$ was detected on group analysis (Table II, Figure 4), indicating that the difference between the two cirrhotic groups of the effect of estrogen administration is quantitative rather than qualitative.

The effect of estrogen on the group of infective hepatitis did not differ from the normal in three cases, but in the fourth (No. 48) estrogen administration was associated with a marked reversal of an existing $\mathrm{NaCl}$ and water diuresis similar to that observed in two cases (Nos. 24 and 28) in the group of cirrhosis with ascites. It is of interest that this (No. 48) was the only case of infective hepatitis in which recovery was not already evident by the time estrogen was administered, suggesting that $\mathrm{NaCl}$ and water retention might have been observed more often if more severe cases had been available.

The prominent increases in weight in the absence of $\mathrm{NaCl}$ retention, observed in some cases of infective hepatitis and cirrhosis without ascites after estrogen, may be attributable to increased tissue formation, as in the normal group (16).

The evidence (12) that, in sub-primates, the liver is the main site of estrogen inactivation is convincing. Although somewhat more controversial (17), the balance of evidence indicates that in humans also estrogens are chiefly inactivated in the liver $(18,19)$.

The marked $\mathrm{NaCl}$ and water storage observed in the present series of cirrhotics with ascites after estrogen administration might be accounted for by failure of a diseased liver to inactivate the hormone. However, the quantitative difference in $\mathrm{NaCl}$ and water retention observed between the two cirrhotic groups would then imply differing rates of hepatic estrogen inactivation. Before 
this thesis can be accepted, various extrahepatic factors, which could account for the findings in the cirrhotics with ascites, must be excluded.

Increased abdominal tension (20) or congestion of the inferior vena cava (21) can cause, at least acutely, a decrease in renal clearance rates. Although the mechanism of renal excretion of estrogens is not known (22), it is possible that the presence of ascites might, by reducing renal clearances through one of the above mechanisms, delay the renal excretion of the estrogen. However, this possibility appears unlikely. No impairment of renal function was demonstrated in this group of cirrhotics with ascites by conventional renal function tests, and glomerular filtration rate and renal plasma flow have been shown to be in general normal in cirrhosis with ascites $(23,24)$ except possibly where ascites is accumulating rapidly (25). (Cases in the latter category were excluded from this study.) Furthermore, in this series marked $\mathrm{NaCl}$ and water retention following estrogen occurred before ascites had developed in case 33, and when ascites was absent in cases 18 and 48. Finally, no alteration in $\mathrm{NaCl}$ and water metabolism attributable to estrogen was observed when the hormone was administered to the group of ascites without hepatic disease.

It is also unlikely that portal hypertension was by itself an important factor in the differing response of the two cirrhotic groups, since firstly, portal hypertension, as judged by the demonstration of esophageal varices on barium swallow, was present in several of the group without ascites (notably Nos. 58 and 70, in whom the effect of estrogen administration did not differ significantly from normal), and secondly the response to estrogen administration in the group of portal hypertension without hepatic disease was within the normal range.

It appears therefore, that the differences observed between the two cirrhotic groups could reasonably be accounted for by differing rates of estrogen inactivation. This process may in turn be dependent on three intrahepatic factors.

There is good evidence that in animals estrogens are excreted in the bile $(26,27)$ and there is some evidence that biliary excretion may also occur in the human (28). If this pathway were important in the human, either for excretion in the feces, or as part of the process of hepatic inactivation, then either extrahepatic biliary obstruction or intrahepatic disorganization of the biliary tree would presumably result in high blood estrogen levels following estrogen administration. However, in the group of extrahepatic biliary obstruction (obstructive jaundice) in this series, although some significant retention of $\mathrm{NaCl}$ and water did occur (Table III) after estrogen administration, this was only of the same order as in the group of cirrhosis without ascites, and was moreover, transient (Figure 4). These observations indicate that failure of biliary excretion of estrogen due to a disorganization of the intrahepatic biliary tree is not mainly responsible for the $\mathrm{NaCl}$ and water retention observed in the group of cirrhosis with ascites following estrogen administration.

Although the process of hepatic inactivation must eventually depend on hepatocellular activity, an adequate hepatic circulation must also be essential. Since evidence from clinical observation, hepatic function studies and hepatic biopsy suggested that hepatocellular damage was rather more severe in our group of cirrhosis without ascites, it appears possible that the factor deciding the rate of hepatic inactivation of administered estrogen in this series, and so the degree of $\mathrm{NaCl}$ and water retention, may be an impairment of the hepatic circulation. Estimated hepatic blood flow is known to be reduced in cirrhosis of the liver (29), but the discrete effects of ascites have not been studied.

Our observations support the view that the action of estrogens may be a factor in the fluid retention of liver disease, since if exogenous estrogen can produce $\mathrm{NaCl}$ and water retention, then endogenous estrogen would be expected to have the same effect, provided that adequate quantities of the hormone were being produced. The findings of increased urinary estrogenic material on bioassay in both chronic $(30,31)$ and acute (32) hepatic disease indicates that estrogen production in these conditions is in fact substantial.

\section{SUMMARY}

1. Daily administration of $10 \mathrm{mg}$. estradiol benzoate caused sustained retention of $\mathrm{NaCl}$ and water in eight of nine cases of hepatic cirrhosis with ascites. 
2. In hepatic cirrhosis without ascites the same dose of estradiol caused $\mathrm{NaCl}$ and water retention only slightly greater than in the normal, in eleven of twelve cases.

3. The effect of estradiol in five cases of jaundice due to extrahepatic biliary obstruction was similar to that in cirrhosis without ascites.

4. In a group of four cases of infective hepatitis estradiol caused significant $\mathrm{NaCl}$ and water retention in one only.

5. In three cases of ascites without hepatic disease and two cases of portal hypertension without hepatic disease, no significant $\mathrm{NaCl}$ and water retention attributable to estradiol administration was demonstrated.

6. Evidence is put forward suggesting that the $\mathrm{NaCl}$-retaining effect of estradiol in the group of cirrhosis with ascites is due to decreased hepatic inactivation of the hormone. This decreased inactivation may in turn be dependent mainly on a disturbance of the hepatic circulation, rather than on hepatocellular damage.

7. The above findings indicate that increased estrogen activity may be a factor in the fluid retention of liver disease.

\section{REFERENCES}

1. Sherlock, S., Diseases of the Liver and Biliary System. Oxford, Blackwell Scientific Publications, 1955 , p. 110 et seq.

2. Labby, D. H., and Hoagland, C. L., Water storage and the movements of body fluids and chlorides during acute liver disease. J. Clin. Invest., 1947, 26, 343.

3. Jones, C. M., and Eaton, F. B., The prognostic significance of a spontaneous diuresis in acute and subacute disease of the liver. New England J. Med., 1935, 213, 907.

4. Adlersberg, D., and Fox, C. L., Changes of the water tolerance test in hepatic disease. Ann. Int. Med., 1943, 19, 642.

5. Post, J., and Patek, A. J., Serum proteins in relation to cirrhosis of the liver. 1. Relation to prognosis and formation of ascites. Arch. Int. Med., $1942,69,67$.

6. Myers, W. K., and Keefer, C. S., Relation of plasma proteins to ascites and edema in cirrhosis of the liver. Arch. Int. Med., 1935, 55, 349.

7. Bjørneboe, M., Brun, C., and Raaschou, F., Colloid osmotic pressure in chronic hepatitis. Arch. Int. Med., 1949, 83, 539.
8. Higgins, G., Kelsall, A. R., O'Brien, J. R. P., Stewart, A. M., and Witts, L. J., Ascites in chronic disease of the liver. Quart. J. Med., 1947, n.s. 16, 263.

9. Butt, H. R., Snell, A. M., and Keys, A., Plasma proteins in hepatic disease. A study of the colloid osmotic pressure of blood serum and of ascitic fluid in venous diseases of the liver. Arch. Int. Med., 1939, 63, 143.

10. Ralli, E. P., Robson, J. S., Clarke, D., and Hoagland, C. L., Factors influencing ascites in patients with cirrhosis of the liver. J. Clin. Invest., 1945, 24, 316.

11. Thorn, G. W., and Engel, L. L., The effect of sex hormones on the renal excretion of electrolytes. J. Exper. Med., 1938, 68, 299.

12. Pearlman, W. H., The chemistry and metabolism of the estrogens in The Hormones, Pincus, G., and Thimann, K. V., Eds., New York, Academic Press Inc., 1948, vol. 1, p. 351.

13. Klatskin, G., and Rappaport, E. M., Gynecomastia due to infectious hepatitis of the homologous serum type. Am. J. M. Sc., 1947, n.s. 214, 121.

14. Bean, W. B., The cutaneous arterial spider: A survey. Medicine, 1945, 24, 243.

15. Morrione, T. G., Effect of estrogens on the testis in hepatic insufficiency. Arch. Path., 1944, 37, 39.

16. Preedy, J. R. K., and Aitken, E. H., The effect of estrogen on water and electrolyte metabolism. I. The normal. J. Clin. Invest., 1956, 35, 423.

17. Zondek, B., and Black, R., Estrone clearance tests in infectious hepatitis. J. Clin. Endocrinol., 1947, 7, 519.

18. Lieberman, S., and Teich, S., Recent trends in the biochemistry of steroid hormones. Pharmacol. Rev., 1953, 5, 285.

19. Tagnon, H. J., Lieberman, S., Schulman, P., and Brunschwig, A., The metabolism of estrogens by the human liver studied in vitro. J. Clin. Invest., 1952, 31, 346.

20. Bradley, S. E., and Bradley, G. P., The effect of increased intra-abdominal pressure on renal function in man. J. Clin. Invest., 1947, 26, 1010.

21. Farber, S. J., Becker, W. H., and Eichna, L. W., Electrolyte and water excretions and renal hemodynamics during induced congestion of the superior and inferior vena cava of man. J. Clin. Invest., 1953, 32, 1145.

22. Smith, H. W., The Kidney. New York, Oxford University Press, 1951, p. 467.

23. Jones, R. A., McDonald, G. O., and Last, J. H., Reversal of diurnal variation in renal function in cases of cirrhosis with ascites. J. Clin. Invest., 1952, 31, 326.

24. Epstein, F. H., Lesser, G. T., and Berger, E. Y., Renal function in decompensated cirrhosis of the liver. Proc. Soc. Exper. Biol. \& Med., 1950, 75, 822.

25. Leslie, S. H., Johnston, B., and Ralli, E. P., Renal function as a factor in fluid retention in patients 
with cirrhosis of the liver. J. Clin. Invest., 1951, 30, 1200.

26. Cantarow, A., Rakoff, A. E., Paschkis, K. E., Hansen, L. P., and Walkling, A. A., Excretion of estrogen in bile. Endocrinology, 1942, 31, 515.

27. Bocklage, B. C., Doisy, E. A., Jr., Elliott, W. H., Thayer, S. A., Nicholas, H. J., and Doisy, E. A., Excretion of radioactive 17-methylestradiol. Federation Proc., 1951, 10, 164.

28. Pearlman, W. H., and Rakoff, A. E., A note on the estrogens in the bile of pregnant woman. Endocrinology, 1949, 44, 199.
29. Bradley, S. E., Ingelfinger, F. J., and Bradley, G. P., Hepatic circulation in cirrhosis of the liver. Circulation, 1952, 5, 419.

30. Rupp, J., Cantarow, A., Rakoff, A. E., and Paschkis, $\mathrm{K}$. E., Hormone excretion in liver disease and in gynecomastia. J. Clin. Endocrinol., 1951, 11, 688.

31. Dohan, F. C., Richardson, E. M., Bluemle, L. W., Jr., and György, P., Hormone excretion in liver disease. J. Clin. Invest., 1952, 31, 481.

32. Gilder, H., and Hoagland, C. L., Urinary excretion of estrogens and 17-ketosteroids in young adult males with infectious hepatitis. Proc. Soc. Exper. Biol. \& Med., 1946, 61, 62. 